\title{
Carbon stability and biochar aging process after soil application
}

\begin{abstract}
During the pyrolysis process for biochar production there is the stabilization of $\mathrm{C}$ in aromatic compounds, which accredits biochar to function as an input for $\mathrm{C}$ sequestration in the soil. The aim of this study was assessing of $\mathrm{C}$ sequestration potential through pyrolyzed biochar in low temperature $\left(350-400^{\circ} \mathrm{C}\right)$, checking the possible deleterious effect in soil organic matter (SOM) and assessing the cation exchange capacity (CEC) alteration, as the biochar is aging.

The research strategy involved, besides the materials characterization, the installation and conduction of two incubations under controlled laboratory conditions.

The evaluation of the biochar stability of C carbon, the effects on SOM and, therefore, the potential for the use of biochar in soil $\mathrm{C}$ sequestration was carried out in a respirometric experiment, with four typical tropical soil samples mixed with eucalyptus biochar dose $\left(0.0,2.5,5.0,10.0\right.$ and $\left.20.0 \mathrm{~g} \mathrm{Ckg}^{-1}\right)$. After 120 days of incubation under non-limiting temperature and moisture conditions, the results showed $\mathrm{C}$ mineralization rates between 0,4 and $9,3 \%$, which demonstrates the high carbon stability in the biochar. Through the ${ }^{13} \mathrm{C}$ technique in soil analysis at the end of the incubation was observed small reductions of original C in SOM for two of the evaluated soils, although gains from biochar application represented more than double the original $\mathrm{C}$ content of soils.
\end{abstract}

The 360-day incubation experiment to evaluate biochar aging, focusing on the generation of negative charges, considered the variation in the presence or absence of soil; moisture and temperature $\left(25\right.$ or $\left.32^{\circ} \mathrm{C}\right)$. Among the factors tested, there was only effect of time on CEC. The increase in CEC was practically $100 \mathrm{mmol} \mathrm{kg}^{-1}$ in one year, which represented a $50 \%$ increase in surface charges due to the biochar aging process.

The research led to the conclusion that biochar must be considered an input to soil $\mathrm{C}$ sequestration, in the reason of its high stability after application, recommending the use of the conservative value of $90 \%$ of the total C applied via biochar rate to environmental accounting related to $\mathrm{C}$ sequestration. In addition, increases in $\mathrm{CEC}$ in biochar treated soils are expected due to biochar surface charges as well as the aging process after application.

Keywords: soil carbon sequestration, biochar mineralization, priming effect, cation exchange capacity, biochar aging
Volume 3 Issue 6 - 2019

\author{
Flavia Vosgrau De Negri Tozzi,' Aline Renee \\ Coscione, I Aline Peregrina Puga, ${ }^{2}$ Cristina \\ Silva Carvalho, ${ }^{3}$ Carlos Eduardo Pellegrino \\ Cerri, ${ }^{4}$ Cristiano Alberto de Andrade ${ }^{2}$ \\ 'Soil and Environmental Resources Center,Agronomic Institute, \\ Brazil \\ ${ }^{2}$ Brazilian Agricultural Research Corporation (Embrapa), \\ Embrapa Environment Unit, Brazil \\ ${ }^{3}$ Graduate Program in Agroecology, State University of \\ Maranhão, Brazil \\ ${ }^{4}$ Soil Science Department, Luiz de Queiroz College of \\ Agriculture, University of São Paulo, Brazil
}

Correspondence: Cristiano Alberto de Andrade, Embrapa Environment, Rodovia SP-340, Km I27,5; Tanquinho Velho CEP: |39|8-| | 0, Jaguariúna, Estado de São Paulo, Brazil, Email cristiano.andrad@embrapa.br

Received: December 19, 2019 | Published: December 30, 2019

\section{Introduction}

The biochar is obtained through biomass pyrolysis in an environment with absence or restriction of $\mathrm{O}_{2}$ availability, which there is a thermochemical transformation of composts in sense of carbon concentration in stable structures similar to charcoal. ${ }^{1}$

The pyrolysis process can be applied in different situations such as the recycling of huge volumes of agricultural and forestry residues, ${ }^{2}$ decreasing the mass to disposal in the environment and eventually eliminating pathogens. ${ }^{3}$

In Brazil there is the availability of charcoal fines, a byproduct of the low temperature pyrolysis process $\left(350\right.$ to $\left.400^{\circ} \mathrm{C}\right)$ for the charcoal production used in the Brazilian steel industry, as a source of heat and carbon monoxide in the blast furnace to steel production, ${ }^{4}$ replacing coal coke, mainly in the production of pig iron. ${ }^{5}$ The charcoal fines are generated at a rate of $150 \mathrm{~kg}$ per ton of charcoal produced, ${ }^{6}$ where part of them (20-40\%) is redirected to the fines injection process or it sold as briquette (CGEE, 2014); and the rest has no specific purpose.
The pyrolysis process stabilizes the biomass $\mathrm{C}$ in compounds more recalcitrant to decomposition, with aromatic structure, ${ }^{7,8}$ different from the compounds originally present. ${ }^{9,10}$ The biochar carbon decomposition half-life is estimated to range from 102 to 107 years ${ }^{11}$ and the average residence time of the most recalcitrant biochar fraction is 556 years. ${ }^{12}$

Thus, the application of charcoal fines in soil, denominated from here as biochar, can assist on global climate changes mitigation, through the $\mathrm{C}$ sequestration in agricultural soil. ${ }^{1,13,10}$

Pyrolysis temperature is recognized as a key factor for the stability of biochar C compounds after soil application, ${ }^{14,15}$ what makes it fundamental to evaluate the potential of biochar $\mathrm{C}$ sequestration from the charcoal manufacturing process for the Brazilian steel industry, where temperatures do not exceed $400^{\circ} \mathrm{C}$.

An important aspect related to carbon balance by the use of biochar concerns the possibility of a "positive priming effect", in which the substantial increase in microbial activity leads to the loss of 
C from soil organic matter. ${ }^{12,16}$ This increase in microbial activity over relatively short periods is caused by bio-oil condensates that remain in solid matter. ${ }^{17}$

In summary, although the application of biochar potentially represents a stable soil $\mathrm{C}$ input, on the other hand there may be partial $\mathrm{C}$ output from soil organic matter due to the priming effect. The final carbon balance can be estimated with relative certainty based on knowledge of the mentioned processes. The qualitative aspect of this mass balance is not so simple, since soil organic matter compounds usually have cation exchange capacity (CEC) values of 1000 to $3000 \mathrm{mmol} \mathrm{kg}^{-1},{ }^{18}$ while the biochar CEC values range from 20 to $800 \mathrm{mmol} \mathrm{kg}_{\mathrm{c}}{ }^{-1} \cdot{ }^{19}$ It is also reasonable to consider that the fraction of organic matter lost due to the stimulation of soil microbial activity is the least humified fraction,$^{20}$ which do not represent the compounds with higher CEC.

In this context of carbon balance in biochar application systems, which encompasses qualitative aspects that are closely related to soil functions in the environment, it is also important to take into account the negative surface charges generated in the process of aging of the biochar in the soil.

In biochar aging, charges are created by oxidation on particles surface, introducing functional groups, such as carboxylic, ${ }^{15}$ which tend to develop negative charges to values usually found in agricultural soils $(\mathrm{pH}>4,0){ }^{21}$ Environmental conditions such as moisture, temperature and microbial activity may alter the magnitude and intensity of surface charge generation in the biochar particles. ${ }^{22}$

The aim of this research was to evaluate the potential of soil carbon sequestration by using low temperature pyrolyzed biochar and the change in CEC with biochar aging to support carbon balance estimates in biochar-applied agricultural systems. Additionally, some factors possibly controlling the biochar aging process were tested, whose motivation is for later technological use to adding value to biochar or its products

\section{Material and methods}

The research strategy involved, besides the materials characterization, the installation and conduction of two incubations under controlled laboratory conditions.

The evaluation of the biochar stability of $\mathrm{C}$ carbon, the effects on soil organic matter (SOM) and, therefore, the potential for the use of biochar in soil $\mathrm{C}$ sequestration was carried out in a respirometric experiment with quantification of the released $\mathrm{CO}_{2}$.

Samples of four typical tropical soil types were used, with variations in texture and initial levels of $\mathrm{C}$ (Table $1 \&$ Table 2): Oxisol 1, Entisol, Oxisol 2 and Oxisol 3.

The soil samples were previously torn, air dried and sieved with a $2 \mathrm{~mm}$ mesh.

The $\mathrm{BC}$ used in this study was produced by the pyrolysis of eucalyptus wood (charcoal fines) at approximately $400^{\circ} \mathrm{C}$. Charcoal fines (particles with diameter $<9,54 \mathrm{~mm}$ ) are residues generated by the production and transportation of charcoal used in the Brazilian steel industry for pig iron production. ${ }^{25}$

For chemical characterization of $\mathrm{BC}$ (Table 3), the $\mathrm{pH}\left(\mathrm{H}_{2} \mathrm{O}\right)$ and electrical. conductivity of $\mathrm{BC}$ were measured according to the International Biochar Initiative. ${ }^{26}$ Elemental composition $(\mathrm{C}, \mathrm{H}$ and N) was determined using an elemental analyzer (Series II 2400;
Perkin Elmer, Waltham, Massachusetts, USA). The ash content was determined following the procedure ASTM D1762-84. ${ }^{27}$ The oxygen content was determined by mass difference, using the following formula: $100 \%-(\mathrm{C}+\mathrm{H}+\mathrm{N}+$ ash $)$. The specific surface area was obtained using the $\mathrm{N}_{2}$-BET method (NOVA 1200 surface area analyzer; Quantachrome, Boynton Beach, Florida, USA). Cation exchange capacity (CEC) was analyzed according to the method of Gaskin et al. ${ }^{28}$ and by the official Ministry of Agriculture, Livestock and Food Supply method. ${ }^{29}$

$$
\begin{aligned}
& O / C \text { molar Ratio }=\frac{O / 16}{C / 12} \\
& H / C \text { molar Ratio }=\frac{H / 1}{C / 12}
\end{aligned}
$$

\section{CEC determined by MAPA method. ${ }^{29}$}

CEC determined by Gaskin et al. ${ }^{28}$ method, with compulsory exchange with ammonium acetate.

The biochar was analyzed in a Fourier Transform Infrared Absorption Spectrophotometer (FTIR) after pellet preparation of samples mixed with potassium bromide. The spectrum was obtained from 4000 to $450 \mathrm{~cm}-1$, with a resolution of $4 \mathrm{~cm}-1$ and 64 scans (Figure 1). The equipment used was Cary 360 - FTIR Spectrometer - Agilent.

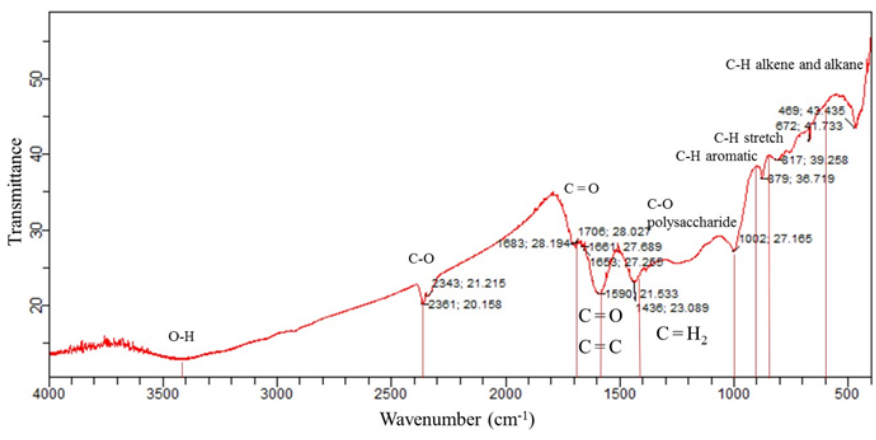

Figure I Medium infrared (FTIR) of the original biochar and signaling of the main functional groups.

A two-factor randomized factorial experiment was performed to evaluate the stability of biochar carbon compounds in soil and effects on SOM. Four soil types with differences in texture (Table 2) and initial C levels (Entisol, Oxisol 1, Oxisol 2 and Oxisol 3 - Table 1) were used and biochar rates of $0.0,2.5,5.0,10.0$ and $20.0 \mathrm{~g} \mathrm{C} \mathrm{kg}^{-1}$, equivalent to $0,5,10,20$ and $40 \mathrm{tC} \mathrm{ha}^{-1}$, respectively.

Each microcosm consisted in a $100 \mathrm{~g}$ of soil or the mixtures of soil with biochar added to a hermetic sealed glass jar $(1,5 \mathrm{~L})$. The incubation was carried in a dark room with controlled temperature $\left(28 \pm 1^{\circ} \mathrm{C}\right)$ for 120 days. The microcosm soil moisture was maintained at $70 \%$ of water holding capacity (WHC) through all the experiment conduction. Moisture was adjusted by weighing each microcosm and adding deionized water when necessary.

In each microcosm, a plastic cup with $50 \mathrm{~mL}$ of sodium hydroxide $\left(\mathrm{NaOH} 0.5 \mathrm{~mol} \mathrm{~L}^{-1}\right)$ solution was placed at soil surface to react with the emitted $\mathrm{CO}_{2}\left(\mathrm{mgCO}_{2}-\mathrm{C} \mathrm{kg}^{-1}\right.$ soil). Microcosms remained sealed until a new solution exchange occurred. Alkaline solution exchange was twice a day or daily at the beginning and spaced at longer intervals over the experiment. 
$\mathrm{CO}_{2}$ evolved from the microcosm was captured in $\mathrm{NaOH}$ solution ${ }^{30}$ and quantified by conductimetric method presented by Rodella and Saboya (1999).

Cumulative $\mathrm{C}-\mathrm{CO}_{2}$ emission results discounted the respective control (soil only, without added biochar) were used to calculate the mineralization rate. Statistical analysis of these results was performed by calculating mean and standard deviation for further discussion about the dispersion of values as a function of soil type and applied rates, as well as comparison with other studies in the literature.

The impact of biochar on $\mathrm{C}$ originally present in MOS was evaluated using ${ }^{13} \mathrm{C}$ analyzes on soil samples after the incubation period to determine the amount of $\mathrm{C}$ remaining soil introduced by biochar. The analyzes were performed in the Laboratory of Ecology Isotopic (LEI) at the Center for Nuclear Energy in Agriculture (CENA) of the University of São Paulo, in elemental analyzer Carlo Elba coupled to mass spectrometer Delta Plus.

To identify the $\mathrm{C}$ origin in the samples, the isotopic mixing equation was applied:

$$
\% C_{\text {Biochar }}=\frac{\left(\delta^{13} C_{\text {Sample }}-\delta^{13} C_{\text {initial soil }}\right)}{\delta^{13} C_{\text {biochar }}-\delta^{13} C_{\text {initial soil }}} \times 100
$$

where:

$\% \mathrm{C}$ biochar $=$ percentage of carbon from biochar; $\delta^{13} \mathrm{C}$ sample $=$ isotopic signal of the soil sample analyzed after incubation;

$\delta^{13} \mathrm{C}$ initial soil $=$ isotopic signal from the original soil sample, i.e. before incubation and without mixture with biochar; and $\delta^{13} \mathrm{C}$ biochar $=$ isotopic signal from biochar sample.

The original soil $\mathrm{C}$ percentage was found by difference: $\% \mathrm{C}$ soil $=100-\% \mathrm{C}$ biochar

The soils Oxisol 1, Entisol, Oxisol 2 e Oxisol 3 originally presented average values of $\delta^{13} \mathrm{C}$ equal to, respectively, $-19,4 \%$; $20,6 \%$; - 19,3\% ; e $-17,26 \%$, contrasting with the average value of biochar equal to $-27,6 \%$.

The results of carbon origin discrimination after the incubation period were submitted to variance analysis and regression analysis for rates of biochar.

The experiment to evaluate biochar aging, focusing on the generation of negative charges, was performed in a quadruple factorial design $(2 \times 2 \times 2 \times 7)$, considering the following variation factors: presence or absence of soil; moisture (constant between 70 and $80 \%$ of WHC or subjected to drying cycles up to $30 \%$ and wetting up to $80 \%$ of WHC); temperature $\left(25\right.$ or $\left.32^{\circ} \mathrm{C}\right)$; and incubation times $(0,15$, $30,60,120,240$ and 360 days). Each microcosm consisted in a $150 \mathrm{~g}$ of soil and/or $30 \mathrm{~g}$ of biochar added to a plastic jar $(250 \mathrm{~mL})$. The soil used in the experiment was Oxisol 1 (Table 1) (Table 2).

Table I Average values (and standard deviation) for some chemical attributes of soils

\begin{tabular}{|c|c|c|c|c|c|c|c|c|c|}
\hline Soil (1) & $\mathrm{pH}^{\prime}$ & SOM & COT $^{2}$ & $\mathbf{P}$ & $\mathbf{K}^{+}$ & $\mathrm{Ca}^{2+}$ & $\mathrm{Mg}^{2+}$ & H+Al & SB $^{3}$ \\
\hline & $\mathrm{CaCl}_{2}$ & $\mathrm{~g} \mathrm{dm}^{-3}$ & $\mathrm{~g} \mathrm{dm}^{-3}$ & $\mathrm{mg} \mathrm{dm}^{-3}$ & \multicolumn{5}{|c|}{$\mathrm{mmol}_{c} \mathrm{dm}^{-3}$} \\
\hline Oxisol I & $\begin{array}{l}4,4 \\
(0,1)\end{array}$ & $\begin{array}{l}10 \\
(0)\end{array}$ & $\begin{array}{l}6 \\
(0)\end{array}$ & $\begin{array}{l}8 \\
\text { (I) }\end{array}$ & $\begin{array}{l}0,9 \\
(0,0)\end{array}$ & $\begin{array}{l}10 \\
(1)\end{array}$ & $\begin{array}{l}4 \\
(0)\end{array}$ & $\begin{array}{l}14 \\
\text { (I) }\end{array}$ & $\begin{array}{l}14,9 \\
(1,4)\end{array}$ \\
\hline Entisol & $\begin{array}{l}4,8 \\
(0,1)\end{array}$ & $\begin{array}{l}8 \\
\text { (I) }\end{array}$ & $\begin{array}{l}5 \\
\text { (I) }\end{array}$ & $\begin{array}{l}5 \\
\text { (I) }\end{array}$ & $\begin{array}{l}0,5 \\
(0,0)\end{array}$ & $\begin{array}{l}8 \\
\text { (I) }\end{array}$ & $\begin{array}{l}4 \\
(0)\end{array}$ & $\begin{array}{l}\text { II } \\
\text { (I) }\end{array}$ & $\begin{array}{l}12,2 \\
(0,5)\end{array}$ \\
\hline Oxisol 2 & $\begin{array}{l}4,8 \\
(0,1)\end{array}$ & $\begin{array}{l}20 \\
(I)\end{array}$ & $\begin{array}{l}12 \\
\text { (I) }\end{array}$ & $\begin{array}{l}11 \\
\text { (I) }\end{array}$ & $\begin{array}{l}1,8 \\
(0,1)\end{array}$ & $\begin{array}{l}37 \\
\text { (I) }\end{array}$ & $\begin{array}{l}16 \\
(0)\end{array}$ & $\begin{array}{l}22 \\
(0)\end{array}$ & $\begin{array}{l}54,9 \\
(0,9)\end{array}$ \\
\hline Oxisol 3 & $\begin{array}{l}5,1 \\
(0,1)\end{array}$ & $\begin{array}{l}\text { II } \\
\text { (I5) }\end{array}$ & $\begin{array}{l}6 \\
(0)\end{array}$ & $\begin{array}{l}7 \\
(3)\end{array}$ & $\begin{array}{l}1,2 \\
(0,0)\end{array}$ & $\begin{array}{l}21 \\
\text { (I) }\end{array}$ & $\begin{array}{l}9 \\
(0)\end{array}$ & $\begin{array}{l}10 \\
(1)\end{array}$ & $\begin{array}{l}31,5 \\
(1,9)\end{array}$ \\
\hline
\end{tabular}

'Soil ( 0 to $20 \mathrm{~cm}$ depth) was analyzed for fertility according to the methodology of van Raij et al..$^{23} \mathrm{pH}$ in solution of $\mathrm{CaCl}_{2}$; SOM in aqueous medium using wet oxidation; $\mathrm{P}, \mathrm{K}^{+}, \mathrm{Ca}^{+2}$ and $\mathrm{Mg}^{+2}$ extracted by ion exchange resin; and $\mathrm{H}+\mathrm{Al}$ determined by $\mathrm{PH}$ SMP buffer.

${ }^{2}$ Total organic carbon determined on an elemental analyzer (TruSpec; LECO, St. Joseph, MI).

${ }^{3}$ Sum of bases calculated by the sum of the contents of $\mathrm{K}^{+}, \mathrm{Ca}^{+2}$ and $\mathrm{Mg}^{+2}$.

Table 2 Mean values (and standard deviation) for soil particle size fractions

\begin{tabular}{lllll}
\hline Soil & Clay' & Silt & Sand & Soil texture classification \\
\hline & $\mathbf{g ~ k g}^{-1}$ & & & \\
\hline \multirow{2}{*}{ Oxisol I } & 163 & 99 & 738 & Sandy loam \\
& $(9)$ & $(12)$ & $(4)$ & \\
Entisol & 137 & 92 & 771 & Sandy clay loam \\
& $(11)$ & $(9)$ & $(5)$ & \\
Oxisol 2 & 457 & 210 & 333 & Clay \\
& $(193)$ & $(20)$ & $(172)$ & \\
Oxisol 3 & 195 & 127 & 678 & Sandy loam \\
& $(3)$ & $(6)$ & $(9)$ & \\
\hline
\end{tabular}

'The particle size of soil ( 0 to $20 \mathrm{~cm}$ depth) was analyzed using the pipette method.$^{24}$ 
The biochar $(30 \mathrm{~g})$ was placed in a polyamide bag $(6 \mathrm{~cm}$ wide and $8 \mathrm{~cm}$ long) and closed to prevent particle loss. In the treatments with biochar and in the presence of soil, the bag containing the biochar was buried in $150 \mathrm{~g}$ of soil.

On the evaluation dates the biochar was removed from the bags, dried at $40^{\circ} \mathrm{C}$ and analyzed for $\mathrm{CTC}, \mathrm{pH}$ and $\mathrm{EC}$. The $\mathrm{pH}$ and $\mathrm{EC}$ were determined following the International Biochar Initiative methods. ${ }^{26}$ The determination of biochar CTC was performed according to Gastkin et al. ${ }^{28}$ by adapting the method described by Summer and Miller ${ }^{31}$ of compulsory exchange with ammonium acetate.

The 240 days incubation biochar samples were sent for analysis of the elemental composition $\mathrm{C}, \mathrm{H}, \mathrm{N}$ and $\mathrm{O}$, using the same methodology used in the initial characterization of the material.

The biochar aging results were submitted to analysis of variance and t-test for comparison of means (qualitative variation factors) and regression analysis for the time of incubation.

\section{Results and discussion}

The biochar had a $\mathrm{pH}$ of $7,8 \pm 0,06$, showing alkaline reaction; and had a CEC by MAPA official method less than $200 \mathrm{mmol}_{\mathrm{c}} \mathrm{kg}^{-1}$ necessary limit to the registry as a soil conditioner. It is important to understand, however, that the official Brazilian method of the Ministry of Agriculture, Livestock and Supply-MAPA ${ }^{32}$ was developed for typical organic materials such as manure and compost, and is based on variable charge sites saturation with hydrogen ions. The biochar has an organic matrix different from original biomass and, because of that, the proposed method by Gaskin et al. ${ }^{28}$ has been most used. Considering the average result of CEC and the standard deviation of

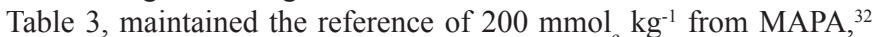
one seen that through alternative method it could be the possibility of the registration as soil conditioner.
The biochar proved to be very concentrated in carbon, overcoming $70 \%$ in mass; which is superior to values close to $50 \%$ of $\mathrm{C}$ in eucalyptus wood. ${ }^{33,34}$ It has been known that during pyrolysis there is an increasing of aromaticity through the establishment of carboncarbon bond and loss of $\mathrm{O}$ and $\mathrm{H},{ }^{34}$ which resulted in $\mathrm{O} / \mathrm{C}$ ratio values of 0,22 and $\mathrm{H} / \mathrm{C}$ of 0,46 less than eucalyptus wood values, equals to 0,67 and 1,45 , respectively. ${ }^{35}$

After comparing band and functional groups of Table 3 with other results from literature, ${ }^{36,37}$ one seen that biochar still presents original peaks of biomass, such as $\mathrm{OH}$ band and cellulose and lignin signs. This is partially explained by the relatively low temperature of pyrolysis, from 350 to $400^{\circ} \mathrm{C}$, which agrees with $\mathrm{H} / \mathrm{C}$ ratio values equals to 0,46 , in the range that indicates simultaneous occurrence of aliphatic and cyclic (aromatic) carbon chains. ${ }^{38}$

The results showed $\mathrm{C}$ mineralization rates between 0,4 and $9,3 \%$ (Table 4) which demonstrates the high carbon stability in the biochar.

Mineralization rates observed are compatible with other results of literature, ${ }^{12}$ given that the higher rates, at a rate of 10 to $15 \%$ of C mineralization, are normally found to low pyrolysis temperature..$^{39,10}$

The difference between soils has become evident when, for example, it compares the Oxisol 3 and the Oxisol 1. One hypothesis initially raised by the research was the possibility of a positive priming effect in response to the application of biochar. In this case, an additional part of $\mathrm{C}-\mathrm{CO}_{2}$ in some treatments (superior to the control) would occur due to the $\mathrm{C}$ mineralization from SOM and not from biochar.

From the ${ }^{13} \mathrm{C}$ results (Table 5), it was possible to verify that in Oxisols 1 and 2 the original carbon remained at the same level, that is, it did not change with increasing biochar rates. For Entisol and Oxisol 3 , reductions in the original $\mathrm{C}$ content of SOM were observed with increasing biochar rate applied.

Table 3 Partial chemical characterization of the biochar used in the experiments

\begin{tabular}{lll}
\hline & Unit & Average value \pm standard deviation \\
\hline $\mathrm{pH}$ & - & $7,7 \pm 0, \mathrm{I}^{*}$ \\
$\mathrm{EC}$ & $\mu \mathrm{S} \mathrm{cm}^{-1}$ & $420 \pm 24$ \\
$\mathrm{Ash}$ & $\%$ & $4,3 \pm 0,6$ \\
$\mathrm{C}$ & $\%$ & $71 \pm 2$ \\
$\mathrm{H}$ & $\%$ & $2,7 \pm 0,2$ \\
$\mathrm{~N}$ & $\%$ & $0,9 \pm 0,2$ \\
$\mathrm{O}$ & $\%$ & $21, \mathrm{I} \pm 0,6$ \\
$\mathrm{O} / \mathrm{C}^{(1)}$ & - & 0,22 \\
$\mathrm{H} / \mathrm{C}^{(2)}$ & - & 0,46 \\
$\mathrm{CEC}(3)$ & $\mathrm{mmol}_{\mathrm{c}} \mathrm{kg}^{-1}$ & $52 \pm 3$ \\
$\mathrm{CEC}\left({ }^{(4)}\right.$ & $\mathrm{mmol}_{\mathrm{c}} \mathrm{kg}^{-1}$ & $184 \pm 18$ \\
$\mathrm{SSA}$ & $\mathrm{m}^{2} \mathrm{~g}^{-1}$ & $16,9 \pm 8,9$ \\
\hline
\end{tabular}


Table 4 Accumulated carbon released as $\mathrm{CO}_{2}\left(\mathrm{C}-\mathrm{CO}_{2}\right)$ within 120 days of soil sample incubation and rates of biochar

\begin{tabular}{|c|c|c|c|c|}
\hline Soil (1) & Rate & $C$ added & $\mathrm{C}-\mathrm{CO}_{2}$ released & Mineralization rates \\
\hline & tha $^{-1} \mathrm{C}$ & $\mathrm{mg} \mathrm{kg}^{-1}$ & mg kg-1 & $\%$ \\
\hline \multirow[t]{4}{*}{ Oxisol I } & 5 & 2516 & $\begin{array}{l}15,00 \\
(0,20)\end{array}$ & $\begin{array}{l}0,60 \\
(0,01)\end{array}$ \\
\hline & 10 & 5032 & $\begin{array}{l}64,62 \\
(22,18)\end{array}$ & $\begin{array}{l}1,28 \\
(0,44)\end{array}$ \\
\hline & 20 & 9990 & $\begin{array}{l}53,40 \\
(15,83)\end{array}$ & $\begin{array}{l}0,53 \\
(0,16)\end{array}$ \\
\hline & 40 & 19980 & $\begin{array}{l}14 \mid, 46 \\
(10,17)\end{array}$ & $\begin{array}{l}0,71 \\
(0,05)\end{array}$ \\
\hline \multirow[t]{4}{*}{ Entisol } & 5 & 2516 & $\begin{array}{l}0,00 \\
(13,16)\end{array}$ & $\begin{array}{l}0,00 \\
(0,55)\end{array}$ \\
\hline & 10 & 5032 & $\begin{array}{l}109,31 \\
(109,55)\end{array}$ & $\begin{array}{l}1,37 \\
(1,93)\end{array}$ \\
\hline & 20 & 9990 & $\begin{array}{l}72,7 I \\
(4 I, 68)\end{array}$ & $\begin{array}{l}0,88 \\
(0,37)\end{array}$ \\
\hline & 40 & 19980 & $\begin{array}{l}228,85 \\
(174,09)\end{array}$ & $\begin{array}{l}0,66 \\
(0,08)\end{array}$ \\
\hline \multirow[t]{4}{*}{ Oxisol 2} & 5 & 2516 & $\begin{array}{l}37,77 \\
(13,8 I)\end{array}$ & $\begin{array}{l}I, 50 \\
(0,55)\end{array}$ \\
\hline & 10 & 5032 & $\begin{array}{l}21,12 \\
(13,04)\end{array}$ & $\begin{array}{l}0,42 \\
(0,26)\end{array}$ \\
\hline & 20 & 9990 & $\begin{array}{l}69,35 \\
(17,22)\end{array}$ & $\begin{array}{l}0,69 \\
(0,17)\end{array}$ \\
\hline & 40 & 19980 & $\begin{array}{l}156,56 \\
(47,09)\end{array}$ & $\begin{array}{l}0,78 \\
(0,24)\end{array}$ \\
\hline \multirow[t]{4}{*}{ Oxisol 3} & 5 & 2516 & $\begin{array}{l}22,92 \\
(51,57)\end{array}$ & $\begin{array}{l}0,91 \\
(2,05)\end{array}$ \\
\hline & 10 & 5032 & $\begin{array}{l}304,83 \\
(100,04)\end{array}$ & $\begin{array}{l}6,06 \\
(1,99)\end{array}$ \\
\hline & 20 & 9990 & $\begin{array}{l}363,65 \\
(17,80)\end{array}$ & $\begin{array}{l}9,31 \\
(5,85)\end{array}$ \\
\hline & 40 & 19980 & $\begin{array}{l}94,63 \\
(13,58)\end{array}$ & $\begin{array}{l}I, 42 \\
(I, 30)\end{array}$ \\
\hline
\end{tabular}

Table 5 Carbon content and the origin discrimination (soil or biochar) in four soil samples after 120 days incubation with rates of biochar

\begin{tabular}{|c|c|c|c|c|c|c|}
\hline & \multicolumn{3}{|l|}{ Oxisol I } & \multicolumn{3}{|l|}{ Entisol } \\
\hline & Total C & Biochar C & Soil C & Total C & Biochar C & Soil C \\
\hline 0 & 0,61 & 0,00 & 0,61 & 0,39 & 0,00 & 0,39 \\
\hline 5 & 0,65 & 0,13 & 0,53 & 0,83 & 0,48 & 0,34 \\
\hline 10 & 0,90 & 0,31 & 0,58 & 0,72 & 0,36 & 0,36 \\
\hline 20 & 1,35 & 0,81 & 0,54 & 0,98 & 0,68 & 0,30 \\
\hline 40 & $\mathrm{I}, 82$ & $\mathrm{I}, 24$ & 0,58 & 1,58 & 1,32 & 0,26 \\
\hline Model & $y=0,582+0,032 x$ & $y=0,013+0,032 x$ & Ns & $y=0,498+0,027 x$ & $y=0,121+0,030 x$ & $y=0,378-0,003 x$ \\
\hline$r^{2}$ & $0,974 *$ & $0,973^{*}$ & - & $0,928 *$ & $0,93 I^{*}$ & $0,910 *$ \\
\hline CV\% & 13,37 & 27,44 & 13,83 & 33,08 & 52,05 & 7,3 \\
\hline
\end{tabular}


Table continue

\begin{tabular}{|c|c|c|c|c|c|c|}
\hline & \multicolumn{3}{|l|}{ Oxisol I } & \multicolumn{3}{|l|}{ Entisol } \\
\hline & Total C & Biochar C & Soil C & Total C & Biochar C & Soil C \\
\hline & & Oxisol 2 & & & Oxisol 3 & \\
\hline & Total C & Biochar C & Soil C & Total C & Biochar C & Soil C \\
\hline 0 & 1,2 & 0 & $\mathrm{I}, 2$ & 0,51 & 0 & $0,5 \mathrm{I}$ \\
\hline 5 & I,445 & 0,2325 & 1,2125 & 0,645 & 0,185 & 0,4625 \\
\hline 10 & I,705 & 0,4825 & 1,2175 & 0,8825 & 0,4125 & 0,47 \\
\hline 20 & 2,1 & 0,925 & $\mathrm{I}, 1725$ & $\mathrm{I}, 28$ & 0,855 & 0,4275 \\
\hline 40 & 3,0075 & $\mathrm{I}, 8325$ & $\mathrm{I}, 1775$ & 2,31 & 1,89 & 0,4225 \\
\hline Model & $y=1,221+0,045 x$ & $y=0,009+0,045 x$ & Ns & $y=0,441+0,045 x$ & $y=-0,046+0,048 x$ & $y=0,487-0,002 x$ \\
\hline$r^{2}$ & $0,999 *$ & $1,000 *$ & - & $0,994 *$ & $0,997 *$ & $0,733^{*}$ \\
\hline CV\% & 3,73 & 9,1 & 3,45 & 4,87 & 7,11 & 7,56 \\
\hline
\end{tabular}

Specialized literature provides information on the negative and positive priming effect due to biochar application. The negative priming effect is explained by the encapsulation of SOM in biochar pores and also due to surface chemical reactions that result in the formation of organo-mineral complexes. ${ }^{40,41}$ The positive priming effect, most often cited in scientific studies with biochar, results from stimulating SOM mineralization by increasing soil microbial activity. ${ }^{12}$

The SOM C reductions for two of the evaluated soils (Table 5) are negligible compared to the total $\mathrm{C}$ increments verified with the biochar dose increase (Figure 2), in agreement with the $\mathrm{C}$ stability results previously discussed. Therefore, biochar should be understood as an input for soil $\mathrm{C}$ sequestration and we recommend using $90 \%$ as a conservative value in accounting for $\mathrm{C}$ increment in production systems with biochar application.

In terms of impact on CEC, as the lost SOM C fraction is negligible and not always occurring, it remains to understand about the charges added via biochar to the soil. Table 3 shows the biochar CEC values determined by two analysis methods. In addition to these values there are the negative charges possibly resulting from biochar aging in the soil, which is discussed below.

There was an expectation that abiotic factors, such as temperature and moisture, would interfere in surface charges generation through change of oxidative process. However, it was only verified time effect in CEC (Figure 3) and neither the absence nor presence of the soil has interfered in the process.

The increase of CEC with the biochar aging is due to the progressive formation of surface carboxylic, phenolic, carbonyl groups. ${ }^{42,43}$

It is important to note that $\mathrm{CEC}$ is a requirement for registration as a product (soil conditioner) in MAPA and that typical organic materials such as manure and compost generally reach the required limit value of $200 \mathrm{mmol} \mathrm{kg}^{-1}$. In the case of biochar, this limit may be a barrier to its registration, but the basic differences between the behavior of typical organic materials and biochar after soil application must be considered. Unlike typical organic materials, biochar practically remains in the soil after application (we recommend using $90 \%$ of total $\mathrm{C}$ for the stable fraction) and still has CEC gains over time (100 mmol $\mathrm{kg}^{-1}$ in one year - Figure 3). Such differences would justify the request for registration as a new product in a specific category for biochar in MAPA.

Surface changes in biochar particles with the aging process involve increased $\mathrm{O} / \mathrm{C}$ ratio, ${ }^{40}$ which was observed in our results. At 240 days of incubation the biochar presented values of $0.25 \pm 0.01$ and $0.49 \pm 0.01$ for the $\mathrm{O} / \mathrm{C}$ and $\mathrm{H} / \mathrm{C}$ ratios, respectively. These values are greater than 0.22 for $\mathrm{O} / \mathrm{C}$ and 0.46 for $\mathrm{H} / \mathrm{C}$ in the original biochar (Table 3 ) and indicate the occurrence of $\mathrm{C}-\mathrm{C}$ bond cleavage and new $\mathrm{O}$ and $\mathrm{H}$ bonds formation with biochar aging. The new $\mathrm{O}$ and $\mathrm{H}$ bonds make the material more aliphatic and polar, which corroborates the increases in CEC.

In order to improve the understanding of aging process of biochar, there was realized FTIR analyses at 240 days of incubation (Figure 4). In general way, both the presence and the absence of soil, the changes in signals of functional groups were quite similar.

In comparison to Figure 1, which shows the analysis of initial biochar sample (without aging), it can be observed in Figure 4 that changes occurred in the band near $2300 \mathrm{~cm}^{-1}$, indicating that the functional group of $\mathrm{C}-\mathrm{O}$ has disappeared from original biochar in relation to treatments. In the band near $1436 \mathrm{~cm}^{-1}$, there was a displacement of $\mathrm{O}-\mathrm{C}-\mathrm{O}$ or aromatic $\mathrm{CH}_{2}$. There was attenuation of bands under $100 \mathrm{~cm}^{-1}$ of aromatic $\mathrm{C}-\mathrm{H}$, alkane $\mathrm{C}-\mathrm{H}$ and alkenes with the disappearing of band in $670 \mathrm{~cm}^{-1}$.

In the near 1100 to $1030 \mathrm{~cm}^{-1}$ band of Figure $4 \mathrm{~b}$, the attenuation of the vibrational stretching of C-O-C in cellulose and hemicellulose is noted. This band can also be seen in Figure $4 \mathrm{a}$, but the changes in the absence of soil were more remarkable.

The set of changes observed suggest the formation of more simple structures by the increasing of linear saturated carbonic chains (break of aromatic $\mathrm{CH}_{2}$, aromatic $\mathrm{C}-\mathrm{H}$ ) and of residual $\mathrm{C}-\mathrm{O}$ and $\mathrm{O}-\mathrm{C}-\mathrm{O}$ 
of cellulosic structures. This loss of signal of $\mathrm{O}$ linked to $\mathrm{C}$ can be suggest a loss of polarity regarding cellulosic structure. However, such hypothesis it was not confirmed because the 240-day incubation $\mathrm{O}-\mathrm{C}$ ration was higher than original biochar.
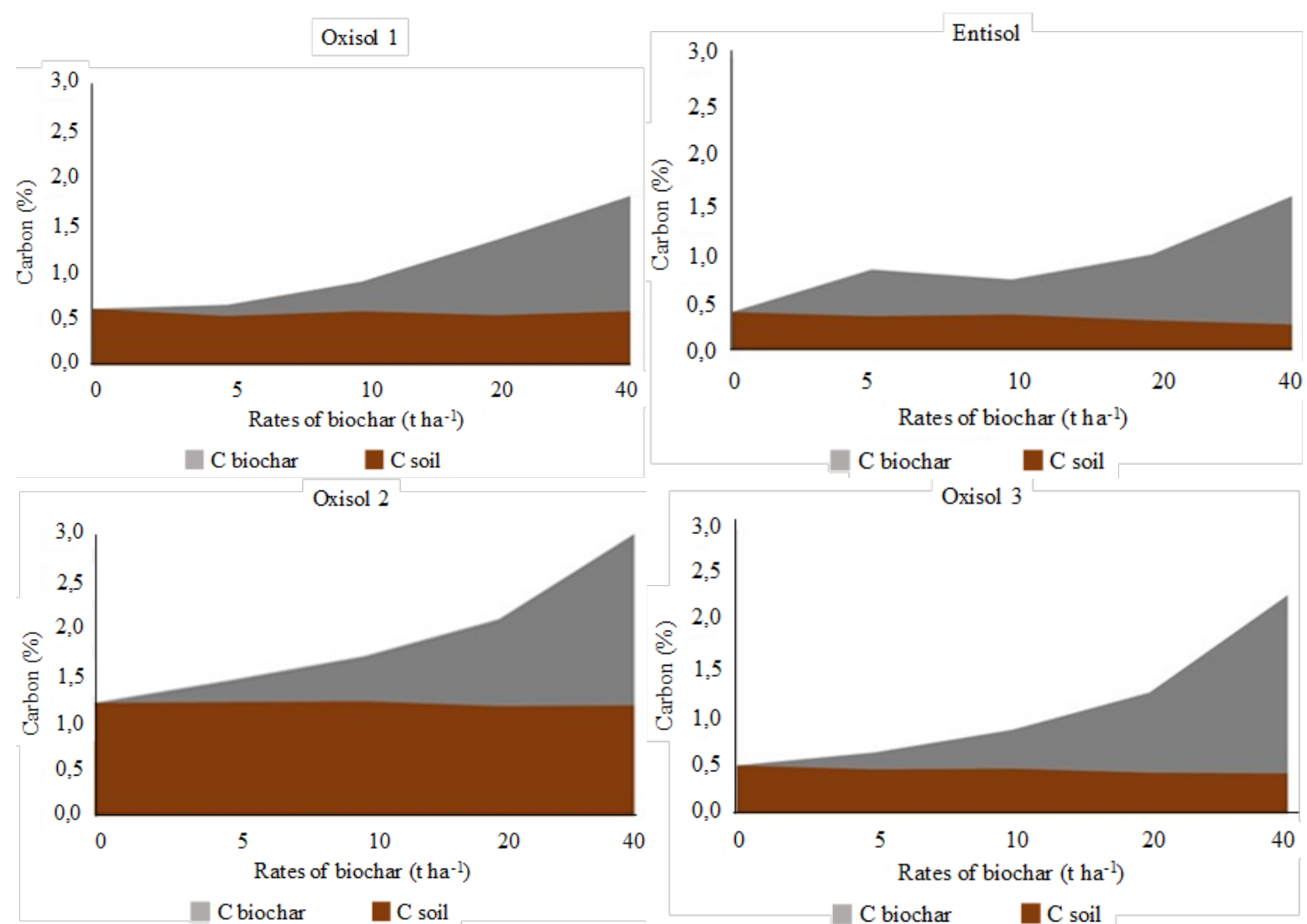

Figure 2 Representation of carbon content variation with origin discrimination (C soil; and C biochar) in four incubated soils during 120 days with rates of biochar.

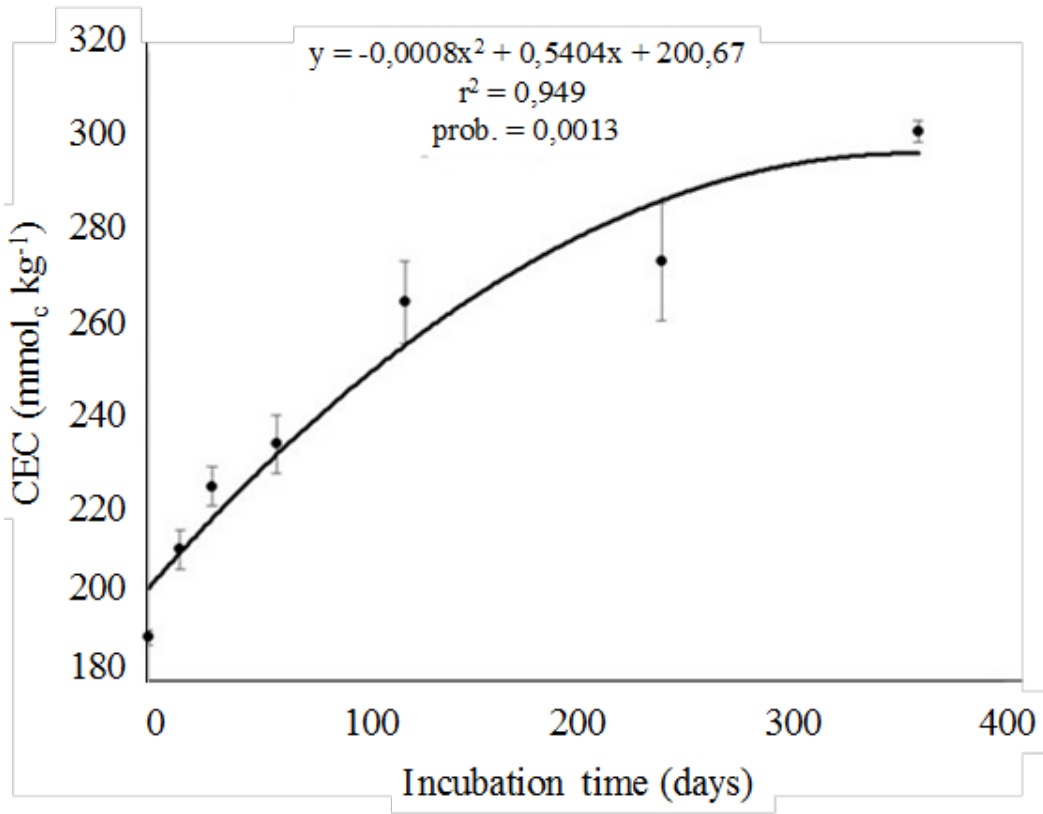

Figure 3 Cation Exchange Capacity (CEC) of biochar in aging process (incubation time). 


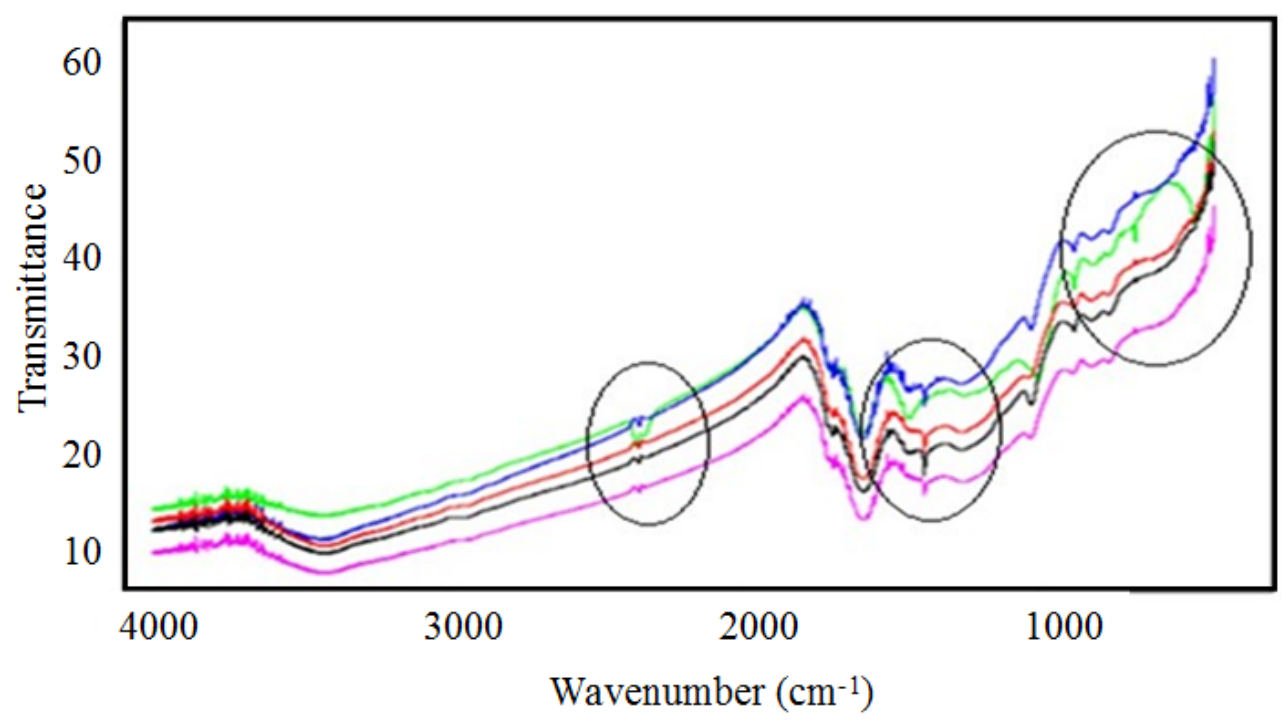

(a)

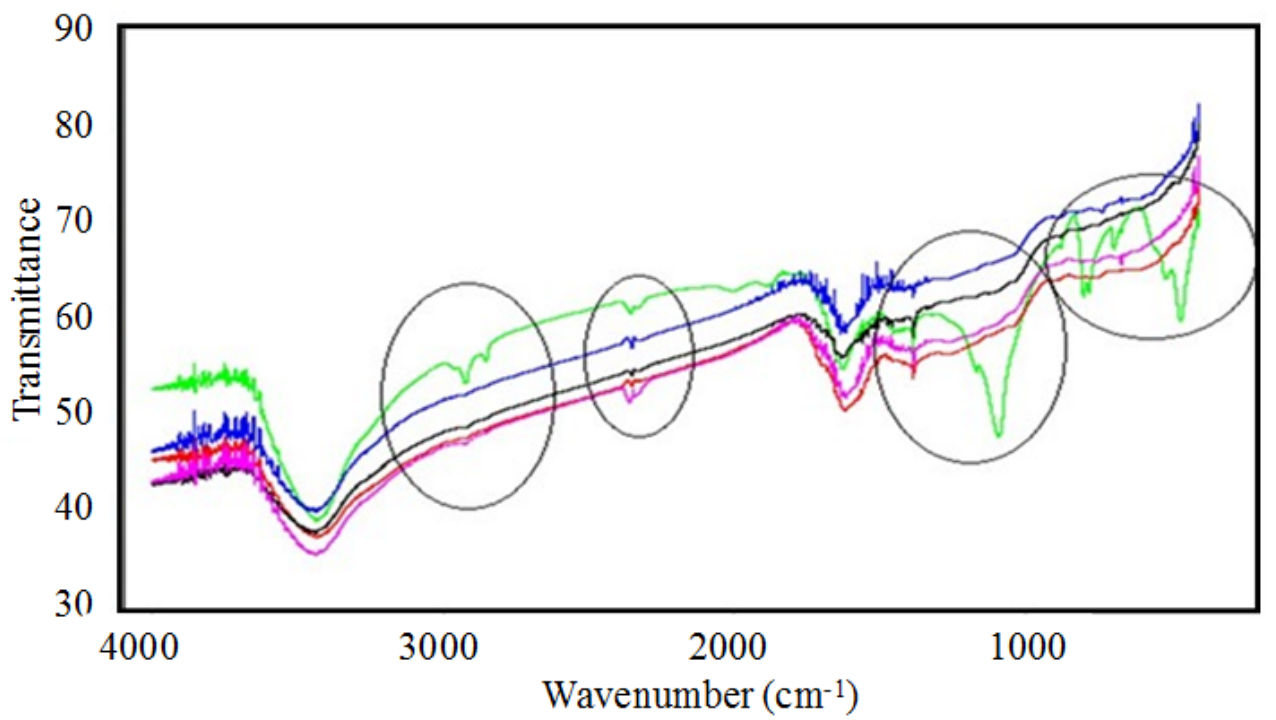

(b)

Figure 4 Fourier transform infrared absorption spectrophotometer (FTIR) analysis of biochar samples aged for 240 days in the presence (a) or absence of soil (b). The lines of different colors represent the combinations with the other variation factors studied (temperature and moisture).

\section{Conclusion}

The biochar must be considered an input to soil carbon (C) sequestration, in the reason of its high stability after application, recommending the use of the conservative value of $90 \%$ of the total $\mathrm{C}$ applied via biochar rate to environmental accounting related to $\mathrm{C}$ sequestration. Losses of original $\mathrm{C}$ from soil organic matter due to the application of biochar are insignificant in terms of mass and in comparison with the observed total carbon increments.

The biochar aging was characterized by the increase of $50 \%$ in cation exchange capacity after one year, but this aging was not influenced by the presence or absence of contact with the soil, with temperature variations and wet and dry cycles. The non-interference of these other factors allows the promotion of biochar aging before its field application, in exclusive or in composting piles, for example.

\section{Acknowledgements}

The authors are grateful for the financial support from São Paulo Research Foundation (FAPESP; Grant No. 2017/02886-7). Also, we would like to thank Felipe Puga for translating the paper.

\section{Conflicts of interests}

Authors declare no conflict of interest exists.

\section{References}

1. Lehmann J, Joseph S. Biochar for environmental management: An Introduction. IN: Lehmann J, Joseph S, editors. Biochar for environmental management: Science and Technology. Earthscan, London. 2009. 
2. Abdelhafez AA, Li J, Abbas MHH. Feasibility of biochar manufactured from organic wastes on the stabilization of heavy metals in a metal smelter contaminated soil. Chemosphere. 2014;117:66-71.

3. Ahmad M, Rajapaksha AU, Lim JE, et al. Biochar as a sorbent for contaminant management in soil and water: a review. Chemosphere. 2014;99:19-33.

4. Protásio TP, Trugilho PF, Mirmehdi S, et al. Quality and energetic evaluation of the charcoal made of babassu nut residues used in the steel industry. Ciênc agrotec. 2014;38:43--444.

5. Manzoni LP, Barros TD. Carvão vegetal. Agência Embrapa de Informação Tecnológica. 2019.

6. Benites VM, Teixeira WG, Pimenta AS, et al. Utilização de Carvão e Subprodutos da Carbonização Vegetal na Agricultura: Aprendendo com as Terras Pretas de Índio. In: Wenceslau GT, Kern DC, et al. editors. As Terras Pretas de Índio da Amazônia: Sua Caracterização e Uso deste Conhecimento na Criação de Novas Áreas. Manaus, Embrapa Amazonia Ocidental. 2009.

7. Roz AL, Ricardo JFC, Nakashima GT, et al. Maximization of fixed carbon content of carbon applied to carbon sequestration. Agriambi. 2015;19:810-814.

8. Tag AT, Duman G, Ucar S, et al. Effects of feedstock type and pyrolysis temperature on potential applications of biochar. JAAP. 2016;120:200206.

9. Alburquerque JA, Salazar P, Barrón V, et al. Enhanced wheat yield by biochar addition under different mineral fertilization levels. Agron Sustain Dev. 2013;33(3):475484.

10. Grutzmacher P, Puga AP, Bibar MPS, et al. Carbon stability and fertilizer induced N2O emissions mitigation in soil treated with biochar. Sci Total Environ. 2018;625:1459-1466.

11. Zimmerman AR. Abiotic and microbial oxidation of laboratory-produced black carbon (biochar). Environ Sci Technol. 2010;44:1295-1301.

12. Wang J, Xiong Z, Kuzyakov Y. Biochar stability in soil: meta-analysis of decomposition and priming effects. GCB Bioenergy. 2016;8:512-523.

13. Liang B, Lehmann J, Solomon D, et al. Stability of biomass-derived black carbon in soils. Geoch Cosmoch Acta. 2008;72:6069-6078.

14. Ouyang L, Yu L, Zhang R. Effects of amendment of different biochars on soil carbon mineralization and sequestration. Soil Res. 2014;52:46-54.

15. Zhang X, Davidson EA, Mauzerall DL, et al. Managing nitrogen for sustainable development. Nature. 2015;528:51-59.

16. Yousaf B, Liu G, Wang R, et al. Investigating the biochar effects on carbon mineralization and sequestration of carbon in soil compared with conventional amendments using the stable isotope $(\delta 13 \mathrm{C})$ approach. Bioenergy. 2017; 9:1085-1099.

17. Smith J, Collins HP, Bailey VL. The effect of young biochar on soil respiration. Soil Biol Biochem. 2010;42:2345-2347.

18. Stevenson FJ. Humus chemistry: genesis, composition, reactions. 2nd ed. John Willey, New York. 1994.

19. Domingues RR, Trugilho PF, Silva CA, et al. Properties of biochar derived from wood and high-nutrient biomasses with the aim of agronomic and environmental benefits. PLoS ONE. 2017;12(5):e0176884.

20. Tivet F, Sá JCM, Lal R, et al. Assessing humification and organic Ccompounds by laser-induced fluorescence and FTIR spectroscopies under conven-tional and no-till management in Brazilian Oxisols. Geoderma. 2013;207-208:71-81.
21. Cheng CH, Lehmann J, Thies JE, et al. Oxidation of black carbon by biotic and abiotic processes. Org Geochem. 2006;37:1477- 1488.

22. Cheng $\mathrm{CH}$, Lehmann J, Engelhard MH. Natural oxidation of black carbon in soils: Changes in molecular form and surface charge along a climosequence. Geochim Cosmochim Acta. 2008;72:1598-610.

23. Raij Bvan, Andrade JC, Cantarella H, et al. Análise química para avaliação da fertilidade de solos tropicais. Agronômico, Campinas. 2001.

24. Camargo OA, Moniz AC, Jorge JA, et al. Chemical, mineralogical and soil physical analysis methods of campinas agronomic institute. Instituto Agronômico, Campinas. 2009.

25. Ministry of mines and energy. National energy balance 2017: ano base 2016. EPE, Rio de Janeiro.Brazil. 2017.

26. https://www.biochar-international.org/wp-content/uploads/2018/04/ IBI_Biochar_Standards_V2.1_Final.pdf

27. ASTM Standard D1762 - 84. Standard test method for chemical analysis of wood charcoal. American Society for Testing and Materials, Philadelphia, USA. 2013.

28. Gaskin JW, Steiner C, Harris K, et al. Effect of low temperature pyrolysis conditions on biochar for agricultural use. American Society of Agricultural and Biological Engineers, Michigan, USA. 2008.

29. Ministério da Agricultura, Pecuária e Abastecimento - MAPA. Manual de métodos analíticos oficiais para fertilizantes minerais, orgânicos, organominerais e corretivos. MAPA/SDA/CGAL, Brasília. 2014.

30. Coscione AR, Andrade CA. Protocols for assessing the dynamics of organic waste in the suno. In: Andrade JC, Abreu MF. chemical analysis of solid waste for monitoring and agro-environmental studies.Instituto Agronômico, Campinas. 2006.

31. Sumner ME, Miller WP. Cation exchange capacity and exchange coefficients. In: Methods of Soil Analysis. SSSA \& ASA, Madison. 1996.

32. Normative instruction n. 35, of July 4, 2006. Specifications and warranties, tolerances, registration, packaging and labeling of acidity, alkalinity and sodicity correctives and soil conditioners. MAPA, 2006.

33. Nakai DK. Potential evaluation of eucalyptus spp. in countercurrent type aerator. master's dissertation in mechanical sciences, department of mechanical engineering, University of Brasilia, Brasilia, 2014;73.

34. Veiga, TRLA; Lima, JT; Dessimoni, et al. Different plant biomass characterizations for biochar production. Cerne. 2017; 23:529-536.

35. Uchimiya M, Chang S, Klasson KT. Screening biochars for heavy metal retention in soil: role of oxygen functional groups. J Hazard Mater. $2011 ; 190: 432-41$

36. Wu W, Yang M, Feng Q, et al. Chemical characterization of rice strawderived biochar for soil amendment. Biomass Bioenerg. 2012;47:268276

37. Mishra V, Kumar MKS, Gupta N, et al. Study on sorption characteristics of uranium onto biochar derived from eucalyptus wood. Water Air Soil Pollut. 2017;228:309.

38. Tozzi FVN. Carbon stability and fine coal aging process: effects on $\mathrm{pH}$, electrical conductivity and cation exchange capacity. Dissertation (Master in Tropical and Subtropical Agriculture) - Agronomic Institute, $2018 ; 70$.

39. Andrade CA, Bibar MPS, Coscione AR, et al. Mineralization and effects of chicken litter biochar on soil cation exchange capacity. Pesq Agropec Bras. 2015;50:407-416. 
40. Ventura M, Zhang C, Baldi E, et al. Effect of biochar addition on soil respiration partitioning and root dynamics in an apple orchard. Eur $J$ Soil Sci. 2014;65:186-195.

41. Chen $\mathrm{C}$, Cheng $\mathrm{C}$, Huang $\mathrm{Y}$, et al. Converting leguminous green manure into biochar: changes in chemical composition and $\mathrm{C}$ and $\mathrm{N}$ mineralization. Geoderma. 2014;232-234:581-588.
42. Mia S, Dijkstra FA, Sinhgh B. Aging induced changes in biochar's functionality and absorption behavior for phosphate and ammonium Environmental Science and Technology. 2017(b);51(15):8359-8367.

43. Mia S, Dijkstra FA, Sinhgh B. Long-term aging of biochar: a molecular understanding with agricultural and environmental implications. Advances in Agronomy. 2017(a);141:1-51. 